\title{
PERILAKU KONSUMEN MOBILE INTERNET DALAM PENGGUNAAN PAKET LAYANAN UNLIMITED
}

\author{
Dwi Hurriyati ${ }^{1}$, Desy Arisandy ${ }^{2}$ \\ Program Studi Psikologi \\ UniversitasBina Darma Palembang \\ Jalan A. Yani No. 12 Palembang \\ Surel: dwi.hurriyati@binadarma.ac.id ${ }_{2}$ desy.arisandy@binadarma.ac.id
}

\begin{abstract}
Indonesia is the most active country in using social media. Indonesia is also the largest online market with the fastest growth in Southeast Asia. This has caused many adult mobile internet users to purchase service packages that are considered satisfactory in terms of both quantity and quality. The phenomenon of internet growth and adult mobile internet users in Indonesia is certainly a potential target of telecommunications operators in marketing products in accordance with the wishes of consumers. The population in this study is consumers of mobile users who are equipped with modems for the internet (mobile internet) aged 18-40 years, especially who bought the unlimited Smartfren service package in Palembang. The sampling technique used was accidental sampling. The measuring instrument used in the form of a scale of mobile internet consumer behavior and purchasing decisions. The analysis technique used is quantitative analysis using simple regression analysis (simple regression) with SPSS Version 20 for Windows aids. Based on the results of data analysis, it is known that the correlation coefficient between mobile internet consumer behavior and purchasing decisions is $r=$ 0.846 with $p=0.000$ where $p \leq 0.01$. Thus, the hypothesis which states that there is a relationship between consumer behavior of mobile internet with the decision to purchase unlimited smartfren service packages in Palembang is proven. Thus, there is a very significant relationship between the behavior of consumers of mobile internet with the decision to purchase an unlimited smartfren service package in Palembang.
\end{abstract}

Keywords: Consumer Behavior, Decisions, Using Mobile Internet, Unlimited Service Packages

Abstrak : Indonesia merupakan negara teraktif dalam menggunakan media sosial. Indonesia juga merupakan pasar online terbesar dengan pertumbuhan tercepat se-Asia Tenggara. Hal ini menyebabkan banyaknya pengguna mobile internet dewasa yang membeli paket layanan yang dianggap memuaskan baik dari segi kuantitas maupun kualitas. Fenomena pertumbuhan internet dan pengguna mobile internet dewasa di Indonesia tentunya menjadi target potensial operator telekomunikasi dalam memasarkan produk yang sesuai dengan keinginan konsumen.Populasi dalam penelitian ini adalah konsumen pengguna handphone yang dilengkapi modem untuk internet (mobile internet) yang berusia 18-40 tahun, khususnya yang membeli paket layanan unlimited smartfren di Palembang. Teknik sampling yang digunakan adalah accidental sampling. Alat ukur yang digunakan berupa skala perilaku konsumen mobile internet dan keputusan pembelian. Teknik analisis yang digunakan adalah analisis kuantitatif menggunakan analisis regresi sederhana (simple regression) dengan alat bantu program SPSS Versi 22 for Windows. Berdasarkan hasil analisis data diketahui hasil nilai koefisien korelasi antara perilaku konsumen mobile internet dengan keputusan pembelian adalah $\mathrm{r}=0,846$ dengan $\mathrm{p}=$ 0,000 dimana $\mathrm{p} \leq 0,01$. Dengan demikian, hipotesis yang menyatakan terdapat hubungan antara perilaku konsumen mobile internet dengan keputusan pembelian paket layanan unlimited smartfren di Palembang terbukti kebenarannya. Dengan demikian, terdapat hubungan yang sangat signifikan antara perilaku konsumen mobile internet dengan keputusan pembelian paket layanan unlimited smartfren di Palembang. 
Kata Kunci: Perilaku Konsumen, Keputusan, Menggunakan Mobile Interet, Paket Layanan Unlimited

\section{PENDAHULUAN}

Pertumbuhan internet dan pengguna mobile internet dewasa di Indonesia tentunya menjadi target potensial bagi operator telekomunikasi dalam memasarkan produk yang sesuai keinginan konsumen saat ini.

Salah satu operator yang setiap bulan selalu mengikuti kebuthan para konsumen adalah Smartfren. Operator telekomunikasi ini juga yang paling banyak dipilih oleh konsumen karena menawarkan paket internet 4G LTE Advanced yang menghadirkan layanan internet 4G unlimited tanpa batasan kuota dan kecepatan yang memiliki banyak keunggulan dibandingkan operator lainnya. Harga beli paket unlimited smartfren ini juga lebih murah jika dibandingkan dengan operator lainnya. Harga paket bulanan termahal untuk smartfren yaitu Rp 200.000 dengan kuota FUP 9 GB. Yang berbeda dengan provider lain, paket internet unlimited smartfren dapat ditambahkan dengan paket booster dimana pengguna dapat menikmati kecepatan lebih tinggi dengan membeli paket booster yang normalnya kecepatan paket unlimited berkecapatan $512 \mathrm{kbps}$ maka dengan booster pengguna akan mendapatkan kecepatan yang lebih besar.
Mobile internet adalah layanan akses internet untuk para pengguna bergerak (mobile user) yang membutuhkan akses internet dimana saja tanpa dibatasi oleh kendala batasan ruang dan kendala tidak adanya ketersediaan kabel di lokasi pengguna (user).

Namun ada juga beberapa konsumen yang memilih membeli paket layanan unlimited selain paket layanan unlimited smartfren. Berdasarkan hasil wawancara, konsumen-konsumen tersebut menyatakan tidak terlalu mengerti tentang produk-produk paket layanan internet yang ditawarkan oleh berbagai operator, mereka masih memilih paket layanan yang lebih terkenal dan sudah banyak digunakan oleh orang lain sebelumnya seperti telkomsel, indosat, dan XL. Selain itu, ada juga beberapa konsumen yang menyatakan bahwa smartfren tidak memiliki koneksi internet yang stabil karena sinyalnya sering hilang. Lalu ada juga yang menyatakan bahwa sinyal smartfren sangat sedikit di kawasan rumahnya sehingga mereka lebih memilih paket layanan internet dari operator lain. Beberapa orang konsumen menyatakan bahwa smartfren memang menawarkan harga yang relatif lebih murah dibandingkan operator lain namun kualitas yang diberikan belum optimal. 
Dalam penelitian ini, subjek penelitian adalah orang-orang yang masuk dalam kategori dewasa awal. Istilah adult atau dewasa awal berasal dari kata adultus yang berarti telah tumbuh menjadi kekuatan atau ukuran yang sempurna atau telah menjadi dewasa. Hurlock (2008) mengatakan bahwa masa dewasa awal dimulai pada umur 18 tahun sampai umur 40 tahun, saat perubahan-perubahan fisik dan psikologis yang menyertai berkurangnya kemampuan reproduktif.

Dalam penelitian ini, peneliti memilih subjek dewasa awal karena dalam rentang usia ini konsumen sudah mempunyai kemandirian ekonomi dan kemandirian dalam membuat keputusan dimana dalam membuat suatu keputusan membeli sebuah produk sudah tidak terpengaruh oleh orang lain.

Keputusan pembelian konsumen adalah membeli merek yang paling disukai dari berbagai alternatif yang ada, tetapi dua faktor bisa berada antara niat pembelian dan keputusan pembelian. Faktor pertama adalah sikap orang lain dan faktor yang kedua adalah faktor situasional. Oleh karena itu, preferensi dan niat pembelian tidak selalu menghasilkan pembelian yang actual (Kotler, 2008).

Ciri-ciri dari keputusan pembelian menurut (Kotler, 2008) yaitu (1) konsumen lebih memilih barang berdasarkan kebutuhannya saja, (2) barang yang akan dipilih konsumen dapat memberikan kegunaan secara optimal untuk konsumen, (3) konsumen akan lebih memilih barang yang mutunya sudah terjamin, (4) konsumen memilih barang yang harganya telah sesuai dengan kemampuan dari para konsumen.

Berdasarkan hasil wawancara yang dilakukan, sebagian besar pembeli paket layanan unlimited menyatakan telah mencari informasi terlebih dahulu tentang paket layanan internet yang sesuai dengan kebutuhannya sebelum membeli kemudian telah mencoba beberapa operator sebelumnya dan melakukan evaluasi hingga akhirnya konsumen lebih memilih paket layanan unlimited smartfren yang menawarkan paket layanan internet dengan kuota tanpa batas dan harga yang murah dengan jaringan yang luas dan cepat.

Konsumen menyatakan lebih memilih produk smartfren karena melihat produk tersebut lebih unggul daripada produk lain yang sejenisnya, produk smartrfren juga dikenal mempunyai jaringan yang cepat dan stabil sehingga banyak yang memilih produk tersebut. Dalam beberapa tahun terakhir produk smartfren merupakan operator yang paling diminati oleh pembeli.

Ada dua faktor yang mempergaruhi pengambilan keputusan pembelian yang Perilaku Konsumen Mobile Internet dalam (Dwi Hurriyati dan Desy Arisandy) 140 
selanjutnya akan menentukan respons konsumen. Pertama, konsumen itu sendiri. Ada dua unsur dari konsumen yang berpengaruh terhadap pengambilan keputusan yaitu pikiran konsumen yang meliputi kebutuhan atau motivasi, persepsi, perilaku konsumen dan karakteristik konsumen yang meliputi demografi, gaya hidup, dan kepribadian konsumen. Faktor kedua adalah pengaruh lingkungan yang terdiri atas nilai budaya, pengaruh sub dan lintas budaya, kelas sosial, face to face group, dan situasi lain yang menentukan (Suryani, 2013). Penelitian seperti ini sudah pernah dilakukan oleh Marheni (2016) dengan judul Pengaruh Perilaku Konsumen terhadap Pembelian Online Produk Fashion pada Zalora Indonesia. Hasil penelitian menunjukkan bahwa perilaku konsumen pada zaman teknologi seperti saat ini secara signifikan berpengaruh pada keputusan pembelian pada Zalora Indonesia.

Perilaku konsumen adalah perilaku yang ditunjukkan oleh konsumen dalam mencari, membeli, menggunakan, mengevaluasi, dan menghentikan konsumsi produk, jasa, dan gagasan (Schiffman dan Kanuk, 2000). Menurut Setiadi (2003), perilaku konsumen adalah tindakan yang langsung terlibat dalam mendapatkan, mengkonsumsi, dan menghabiskan produk atau jasa, termasuk proses keputusan yang mendahului dan menyusuli tindakan ini.
Perilaku konsumen melibatkan pemikiran dan perasaan yang mereka alami serta tindakan yang mereka lakukan. Selain itu, mayoritas konsumen memerlukan pemikiran yang matang dalam mengambil keputusan pembelian dengan membandingkan produk yang sesuai dengan kebutuhan dan keinginan konsumen tersebut sehingga konsumen telah mencari informasi terlebih dahulu tentang paket layanan internet yang sesuai dengan kebutuhannya sebelum membeli kemudian telah mencoba beberapa operator sebelumnya dan melakukan evaluasi hingga akhirnya konsumen lebih memilih paket layanan unlimited smartfren. Selain itu, konsumen mengambil keputusan pembelian dengan didasari sifat yang ada di dalam dirinya, salah satunya rasa ingin dihargai, dihormati, dan untuk memenuhi kebutuhan serta keinginannya.

Konsumen yang membeli layanan unlimited smartfren sudah tidak mudah lagi terpengaruh dalam pemilihan, dalam hal ini pemilihan produk layanan unlimited berdasarkan kebutuhan sendiri bukan mengikuti orang lain. Sedangkan perilaku konsumen dalam memilih sebuah produk berdasarkan alasan yang di terima. Perilaku konsumen juga menentukan pilihan berdasarkan dorongan dalam diri.

Keputusan intuitif lebih tepat untuk masalah-masalah bersifat kemanusiaan, 
pengambilan keputusan didasarkan pada intuisi atau perasaan dan naluri yang dihasilkan dari serangkaian proses pengalaman dimana mereka sudah beberapa kali mencoba merek paket layanan dari berbagai operator hingga akhirnya memutuskan memilih paket layanan unlimited smartfren. Pengambilan keputusan secara intuisi seringkali terjadi karena kurang lengkapnya informasi yang diterima oleh konsumen.

Perilaku konsumen menurut Terry (2006) yaitu pengambilan keputusan rasional, bahwa keputusan yang diambil dengan menggunakan pendekatan rasional atau melakukan rasionalisasi dengan menggunakan logika atau pemikiran yang terpola dimana konsumen sebelum memutuskan membeli paket layanan unlimited smartfren menggunakan logika tentang produk tersebut.

Pengambilan keputusan berdasarkan data dan fakta empiris dimana mayoritas dari konsumen sebelumnya sudah pernah membeli paket layanan smartfren sehingga sudah mendapatkan fakta tentang kualitas dan keunggulan dari paket layanan yang ditawarkan oleh smartfren sehingga mereka tidak ragu untuk membeli lagi. Keputusan berdasarkan fakta dapat memberikan keputusan yang sehat, solid dan baik. Dengan fakta, tingkat kepercayaan terhadap 
Populasi bukan sekedar jumlah yang ada pada objek atau subjek yang dipelajari, tetapi meliputi seluruh karakteristik atau sifat yang dimiliki oleh objek atau subjek itu. Populasi dalam penelitian ini adalah konsumen pengguna handphone yang dilengkapi modem untuk internet (mobile internet) yang berusia 18-40 tahun, khususnya yang membeli paket layanan unlimited smartfren di Palembang.

Adapun teknik pengambilan sample yang digunakan pada penelitian ini adalah teknik accidental sampling. Menurut Sugiyono (2014) accidental sampling adalah teknik pengambilan sampel secara tidak sengaja atau secara acak yaitu siapa saja yang secara kebetulan bertemu dengan peneliti dapat digunakan sebagai sampel, bila dipandang orang yang kebetulan ditemui itu cocok sebagai sumber

Metode pengumpulan data yang digunakan dalam penelitian ini adalah dengan metode skala. Skala keputusan pembelian dibuat berdasarkan aspek keputusan pembelian yang diungkapkan oleh Swastha (2018) yaitu (1) aspek rasional, (2) aspek emosional, (3) aspek behavioral. Skala perilaku konsumen dibuat berdasarkan tipe-tipe perilaku konsumen yang dikemukakan oleh Simamora (2013) yaitu (1) perilaku membeli yang rumit (2) perilaku membeli untuk mengurangi keragu-raguan (3) perilaku membeli berdasarkan kebiasaan, (4) perilaku membeli yang mencari keragaman.

Jika asumsi/ prasyarat terpenuhi, analisis data yang digunakan untuk mengetahui korelasi antara variabel bebas dan variabel terikat yaitu hubungan antara perilaku konsumen dengan keputusan pembelian, maka hipotesis diuji dengan menggunakan teknik analisis regresi sederhana (simple regression).

\section{HASIL DAN PEMBAHASAN}

Dari hasil deskripsi data berdasarkan kategori keputusan pembelian menunjukkan bahwa dari 546 konsumen di Palembang yang dijadikan subjek penelitian, terdapat 365 dl atau $67 \%$ yang memiliki keputusan pembelian yang tinggi dan 181 konsumen atau $33 \%$ memiliki keputusan pembelian yang rendah. Sehingga dapat disimpulkan rata-rata di Palembang memiliki keputusan pembelian yang tinggi.

Keputusan pembelian yang tinggi menuntut bahwa tingkat kekuatan yang tinggi dibangkitkan terhadap konsumen dan bahwa kekuatan diarahkan menuju pada aktivitas konsumen tertentu. Seseorang dengan keputusan pembelian yang tinggi cenderung lebih banyak berpikir atau lebih bisa merasakan. Pada konsumen yang memiliki keputusan pembelian yang tinggi, mereka akan berpikir lebih keras tentang keputusan yang dilakukan. Konsumen juga 
lebih suka melakukan proses keputusan yang ekstensif dan bergerak melalui setiap tahap keputusan secara berhati-hati (Mowen, 2012). Hal ini juga terjadi di Palembang dimana rata-rata konsumen berpikir terlebih dahulu sebelum membeli paket internet.

Sedangkan keputusan pembelian yang rendah bagi seorang menyatakan bahwa kondisi keterlibatan yang rendah. Keputusan pembelian yang rendah akan terjadi ketika konsumen tidak memiliki kekuatan untuk berpikir atau merasakan (Mowen, 2002). Dalam proses pembelian suatu produk, konsumen mempertimbangkan beberapa merek dan dalam mengevaluasi merek menggunakan sedikit atribut. Keputusan pembelian yang rendah menyebabkan konsumen lebih banyak mempertimbangkan beberapa merek sebelum menetukan pilihan (Sherif, 2018).

Untuk kategori perilaku konsumen mobile internet didapatkan hasil bahwa dari 546 konsumen di Palembang yang dijadikan subjek penelitian, terdapat 350 dewasa awal atau $64 \%$ memiliki perilaku konsumen mobile internet yang tinggi dan 150 konsumen atau $36 \%$ memiliki perilaku konsumen mobile internet yang rendah. Sehingga dapat disimpulkan bahwa rata-rata di Palembang memiliki perilaku konsumen mobile internet yang tinggi dimana konsumen yang pada saat membeli kuota internet di counter-counter sudah tidak lagi mencoba beberapa provider, walaupun harga kuota internet provider tersebut cukup relatif murah konsumen akan tetap membeli kuota tersebut karena sudah konsumen memiliki kualitas jaringan yang sangat bagus dan mendapatkan akses internet tanpa batas atau unlimited dan tidak ragu akan membeli lagi.

Bentuk konsumen dengan perilaku konsumen yang tinggi biasanya terjadi pada tipe pembelian dengan karakteristik produk, antara lain mahal, menimbulkan konsekuensi personal yang serius atau dapat merefleksikan citra sosial seseorang. Untuk tujuan ini, konsumen melewati tahapan mencari informasi, mempertimbangkan banyak atribut produk dan merek, bentuk sikap dan promosi serta memiliki keterlibatan yang tinggi dalam proses pembelian. Pada tipe ini, konsumen terlebih dahulu mencari berbagai informasi atas merek-merek produk yang diinginkannya, kemudian setelah melakukan pembelian dan merasakan kepuasan, konsumen akan mempercayai merek tersebut (Berkowitz, et al., 2015).

Sedangkan pada perilaku konsumen rendah, konsumen membentuk kepercayaan terhadap merek bukan karena mencari merek produk itu, tetapi merek produk yang Perilaku Konsumen Mobile Internet dalam . (Dwi Hurriyati dan Desy Arisandy) 144 
dipercayainya

datang

sendiri

menghampirinya melalui iklan di televisi atau radio atau karena produk tersebut lebih terkenal. Konsumen biasanya tidak melakukan evaluasi terhadap merek produk yang akan dibelinya, sedangkan pada high involvement (keterlibatan tinggi) konsumen menentukan merek-merek yang tersedia dievaluasi terlebih dahulu baru kemudian konsumen memutuskan pembelian (Berkowitz, et al., 2015).

\section{Menurut Kotler (2018), perilaku} konsumen adalah studi bagaimana individu, kelompok dan organisasi memilih, membeli, menggunakan dan menempatkan barang, jasa, ide atau pengalaman untuk memuaskan keinginan dan kebutuhan merekaoleh orang lainya maupun keinginan dirinya sendiri karena orang lain menampilkan perilaku tersebut. Sedangkan menurut Schiffman dan Kanuk (2014) mendeskripsikan perilaku konsumen sebagai perilaku yang diperlihatkan konsumen dalam mencari, membeli, menggunakan, mengevaluasi dan menghabiskan produk dan jasa yang mereka harapkan akan memuaskan kebutuhan mereka. Menurut Hawkins, Best, dan Coney (2011) perilaku konsumen adalah studi mengenai individu, kelompok atau organisasi dan proses dimana mereka menyeleksi, menggunakan dan membuang produk, layanan, pengalaman atau ide untuk memuaskan kebutuhan dan dampak dari proses tersebut pada konsumen dan masyarakat.

Ada dua faktor yang mempengaruhi pengambilan keputusan pembelian yang selanjutnya akan menentukan respons konsumen. Pertama, konsumen itu sendiri. Ada dua unsur dari konsumen yang berpengaruh terhadap pengambilan keputusan yaitu pikiran konsumen yang meliputi kebutuhan atau motivasi, persepsi, perilaku konsumen dan karakteristik konsumen yang meliputi demografi, gaya hidup, dan kepribadian konsumen. Faktor kedua adalah pengaruh lingkungan yang terdiri atas nilai budaya, pengaruh sub dan lintas budaya, kelas sosial, face to face group, dan situasi lain yang menentukan (Suryani, 2018).

Menurut Stanton (2017) keputusan pembelian sebagai proses dalam pembelian nyata setelah melalui taha-tahap sebelumya. Setelah melakukan evaluasi atas sejumlah alternatif maka konsumen dapat memutuskan apakah suatu produk akan dibeli atau diputuskan untuk tidak dibeli sama sekali. Sedangkan menurut Boyd,dkk (2017) pengambilan keputusan pembelian merupakan sebuah pendekatan penyelesaian masalah pada kegiatan manusia membeli suatu produk guna memenuhi keinginan dan kebutuhan. 
Proses pengambilan keputusan terdiri dari empat tahap. Pada tahap pertama merupakan pemahaman akan adanya masalah. Tahap berikutnya terjadi evaluasi terhadap alternatif yang ada dan tindakan yang paling sesuai dipilih setelah itu pembelian diwujudkan dalam bentuk tindakan. Dan akhirnya barang yang dibeli akan digunakan (Engel dkk, 2015).

Tahapan-tahapan keputusan pembelian seperti yang dikemukakan Engel (2015) juga didapati pada konsumen dewasa awal di Palembang dimana dalam memutuskan membeli suatu paket layanan internet, sebagian besar konsumen memahami akan kebutuhan internet yang diperlukan kemudian mengevaluasi paketpaket layanan internet yang sudah pernah dibeli sebelumnya hingga akhirnya menjatuhkan pilihan pada paket yang sesuai dengan kebutuhannya dan akhirnya menggunakan paket layanan internet tersebut.

Penelitian yang dilakukan oleh Ying Ping Liang (2012) dengan judul The Relationship Between Consumer Product Involvement, Produk Knowledge And Impulsive Buying Bahavior. Dengan hasil dari penelitian tersebut adalah bahwa semakin tinggi keterlibatan produk konsumen, semakin tinggi pula pengetahuan produk dan perilaku pembelia impuls.
Penelitian mengenai pengaruh faktor budaya, sosial, pribadi dan psikologi terhadap perilaku pembelian dilakukan oleh Roedjinandari (2006) dengan judul Pengaruh Faktor-Faktor Perilaku Konsumen terhadap Keputusan Pembelian Makanan Khas Jawa pada Rumah Makan Inggil Malang. Penelitian ini diuji dengan analisis deskriktif dari hasil penelitian menunjukan bahwa adanya hubungan yang signifikan dari variabel kelompok referensi sebagai variabel yang berpengaruh terhadap keputusan pembelian dirumah makan Inggil Malang.

Berdasarkan skala yang telah peneliti sebar dapat diketahui bahwa konsumen melakukan evaluasi terlebih dahulu sebelum membeli atau menggunakan suatu provider karena konsumen tidak ingin setelah membeli atau menggunakan suatu provider tersebut mendapatkan kekecewaan akibat provider yang tidak sesuai dengan harapan dan keingin konsumen, walaupun harganya cukup mahal namun jika sesuai harapan dan keinginan dari konsumen maka konsumen tersebut akan tetap membeli atau menggunakan provider yang sesuai dengan harapannya.

\section{SIMPULAN}

Berdasarkan uraian dan hasil analisis data di atas, peneliti menyimpulkan bahwa hipotesis 
yang diajukan oleh peneliti yaitu ada hubungan antara perilaku konsumen mobile internet dengan keputusan pembelian paket layanan unlimited smartfren di Palembang. Dalam penelitian ini, hipotesis tersebut dapat diterima. Adapun bunyi dari hipotesis penelitian ini berdasarkan hasil analisis data yang telah dilakukan adalah ada hubungan yang sangat signifikan antara perilaku konsumen mobile internet dengan keputusan pembelian paket layanan unlimited smartfren di Palembang.

\section{DAFTAR RUJUKAN}

Azwar, S. (2012). Metode Penelitian. Yogyakarta: Pustaka Pelajar.

Berkowitz. (2015). Marketing Third Edition. Boston: Irwin.

Boyd, Walker, Larreche. (2017). Manajemen Pemasaran, Dialihbahasakan oleh Nurmawan, Imam, Edisi kedua, Jilid kedua, Jakarta: Erlangga.

Engel, James, F, Roger D. Blackwell, dan Paul W. Miniard. (2015). Perilaku Konsumen. Edisi Keenam. Jilid 1. Penerbit Binarupa Aksara. Jakarta.

Hawkins, Del I ,J Best, Roger, dan Coney, Kenneth A. (2011). Consumer Behavior: Building Marketing Strategy. The McGraw-Hill.

Hurlock, E. (2008). Psikologi Perkembangan Edisi 5. Jakarta: Erlangga.

Kotler, Amstrong. (2008). Prinsip-prinsip Pemasaran. Jilid 1 dan 2. Edisi 12. Jakarta: Erlangga
Marheni, Eka. (2016). Pengaruh Perilaku Konsumen terhadap Pembelian Online Produk Fashion pada Zalora Indonesia. Vol. 15 No.2, Agustus 2016.

Mowen, Minor. (2012). Perilaku Konsumen. Penerbit Erlangga: Jakarta.

Purwitasari, dkk. (2012). Pengaruh Perilaku Konsumen Dalam Pengambilan Keputusan Pembelian Produk Kfc (Studi Kasus Di Restoran Kfc Cabang Kawi Malang). Vol. 2 no. 1

Schiffman dan Kanuk. (2014). Perilaku Konsumen. Edisi Kedua. Jakarta: PT. Indeks Gramedia

Setiadi, Nugroho. (2003). Perilaku Konsumen Konsep dan Implikasi untuk Strategi dan Penelitian Pemasaran. Jakarta: Kencana.

Sherif, M. (2018). In common predicament: Social Psychology of Intergroup Conflict and Cooperation. Boston: Houghton-Mifflin

Stanton, William. (2017). Fundamental of Marketing. Tokyo: Graw Hill Book.

Sugiyono. (2014). Metode Penelitian Pendidikan Pendekatan Kuantitatif, Kualitatif Dan R\&D. Bandung: Alfabeta.

Suryani, Tatik. (2018). Perilaku Konsumen di Era Internet. Yogyakarta: Graha Ilmu.

Swastha, Basu. (2018). Asas-asas Marketing. Edisi 3. Yogyakarta. Liberty. 1998. Manajemen Pemasaran Modern. Edisi 2. Cetakan II. Yogyakarta : Liberty.

Terry, George. (2006). Principles of Management. (Alih bahasa: Winardi), Alumni Bandung. 